\title{
MECHANICAL AND STRUCTURAL CHARACTERISTICS OF ATMOSPHERIC PLASMA-SPRAYED MULTIFUNCTIONAL $\mathrm{TiO}_{2}$ COATINGS
}

\author{
MEHANSKE IN STRUKTURNE LASTNOSTI \\ VEČFUNKCIONALNEGA OKSIDNEGA NANOSA NA OSNOVI \\ $\mathrm{TiO}_{2}$, IZDELANEGA Z ATMOSFERSKIM PLAZEMSKIM \\ NAPRŠEVANJEM
}

\author{
Mihailo Mrdak ${ }^{1}$ Darko Bajić2 ${ }^{*}$, Darko Veljić1, Marko Rakin ${ }^{3}$ \\ ${ }^{1}$ University of Belgrade, Innovation Center, Faculty of Technology and Metallurgy, 4 Karnegijeva Str., 11000 Belgrade, Serbia \\ ${ }^{2}$ University of Montenegro, Faculty of Mechanical Engineering, Bul. Džordža Vašingtona bb, 81000 Podgorica, Montenegro \\ ${ }^{3}$ University of Belgrade, Faculty of Technology and Metallurgy, 4 Karnegijeva Str., 11000 Belgrade, Serbia
}

Prejem rokopisa - received: 2020-03-30; sprejem za objavo - accepted for publication: 2020-07-22

doi: $10.17222 /$ mit.2020.052

Titanium dioxide $\left(\mathrm{TiO}_{2}\right)$ is a multifunctional oxide that is an interesting material for many technological applications. This paper presents the mechanical properties and microstructure of $\mathrm{TiO}_{2}$ coatings resistant to dry sliding friction, corrosion, grain abrasion and erosion of particles at operating temperatures up to $540{ }^{\circ} \mathrm{C}$. Layers of $\mathrm{TiO}_{2}$ coatings have been successfully deposited on test samples of steel C. 4171 (X15Cr13 EN10027) using the atmospheric plasma spray (APS) process with plasma gun distances of $100 \mathrm{~mm}$ and $110 \mathrm{~mm}$ from the substrate. The APS procedure is used to produce relatively thick coatings of biocompatible and antibacterial $\mathrm{TiO}_{2}$ ceramic coatings for orthopedic applications. The coatings were deposited using the Plasmadyne company plasma spray system and Metco 102 powder, whose particles have an angular morphology produced by the melting and grinding cast blocks. The evaluation of the mechanical properties of the layers was made using the microhardness testing method $\mathrm{HV}_{0.3}$ and the tensile bond strength by tension testing. The analysis of the microstructure of the sprayed $\mathrm{TiO}_{2}$ coating layers was made in accordance with the Pratt \& Whitney standard, using optical microscopy (OM). The morphology of the powder particles, the surface of the deposited coating and the coating fractures were examined by scanning electron microscopy Tests have shown that the layers of $\mathrm{TiO}_{2}$ coatings deposited with a plasma spray distance of $110 \mathrm{~mm}$ have good mechanical properties and microstructure, which allow its use in the development of biomedical implants.

Keywords: atmospheric plasma spray, microstructure, microhardness, bond strength, titanium dioxide

Titanov dioksid $\mathrm{TiO}_{2}$ je večfunkcionalni (večopravilni) material, ki je zanimiv za uporabo v mnogih tehnoloških aplikacijah. V tem članku avtorji predstavljajo mehanske lastnosti in mikrostrukturo $\mathrm{TiO}_{2}$ plasti, odpornih proti suhemu drsnemu trenju, koroziji, abraziji kristalnih zrn in eroziji z delci do temperatur $540{ }^{\circ} \mathrm{C}$. Plasti $\mathrm{TiO}_{2}$ so avtorji uspešno nanesli na podlago iz jekla C.4171 (X15Cr13 EN10027) s postopkom atmosferskega plazemskega naprševanja (APS) s plazemsko puško oddaljeno 100 oz. $110 \mathrm{~mm}$ od podlage. Z APS-postopkom so izdelali relativno debel nanos biokompatibilne in antibakterijske plasti $\mathrm{TiO}_{2}$,

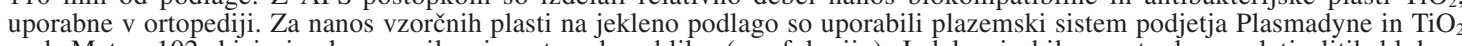
prah Metco 102, ki je imel nepravilno in ostrorobo obliko (morfologijo). Izdelan je bil s postopkom mletja litih blokov. Mehanske lastnosti nanosa so ovrednotili $\mathrm{z}$ določitvijo njegove mikrotrdote $\mathrm{HV}_{03}$ in natezne trdnosti vezi med nanosom in podlago. Analizo mikrostrukture napršenih $\mathrm{TiO}_{2}$ plasti so izvedli s pomočjo optične mikroskopije v skladu s standardom Pratt \& Whitney. Morfologijo prašnih delcev, površino plazemsko napršenih nanosov in njihove prelome so analizirali s pomočjo vrstičnega elektronskega mikroskopa. Testi so pokazali, da imajo izdelane plasti $\mathrm{TiO}_{2}$, napršene s plazmo z razdalje 110 mm, dobre mehanske lastnosti in ustrezno mikrostrukturo, ki dovoljuje njihovo uporabo za biomedicinske vsadke (implantate).

Ključne besede: atmosfersko plazemsko naprševanje, mikrostrukture, mikrotrdota, trdnost vezi, titanov dioksid

\section{INTRODUCTION}

Coatings of pure titanium dioxide $\left(\mathrm{TiO}_{2}\right)$ are multifunctional due to their good properties such as high hardness, density, tensile bond strength, chemical stability, resistance to oxidation and wear, good biocompatibility and antibacterial properties, and photo-electrochemical properties and a high dielectric constant. ${ }^{1-6}$ Due to these properties $\mathrm{TiO}_{2}$ is widely used in the development of biomedical implants, solar cells, photo-catalysts, corrosion protection and chemical oxidation, in optics, electronics,

*Corresponding author's e-mail:

darko@ucg.ac.me (Darko Bajić) etc. ${ }^{7-10}$ When using $\mathrm{TiO}_{2}$ in biomedicine, it was found that an implant with a surface of a bio-ceramic coating such as $\mathrm{TiO}_{2}$, can accelerate the process of healing of the bone, so that it increases long-term implant fixation and stability. ${ }^{11,12} \mathrm{TiO}_{2}$ deposits are generally considered bioinert as they do not initiate interactions in contact with biological tissues. This makes them superior to other biomedical coatings, primarily because of their excellent corrosion resistance and high adhesion to various base materials. ${ }^{13} \mathrm{TiO}_{2}$ coatings are widely used to protect against abrasion, erosion and friction wear either in pure form or in combination with other compounds up to temperatures $\leq 540{ }^{\circ} \mathrm{C} .{ }^{14} \mathrm{TiO}_{2}$ powders of different labels of 
Metco produced by melting and subsequent grinding of the cast blocks are similar in chemical composition, manufacturing process and the morphology of the powder particles. Powders differ in the particle size distribution, which has an influence on the density of the coating. A smaller distribution of granules and finer powders produced thicker coatings. For wear and corrosion, harder and denser coatings are preferred. For applications that require a thicker coating, some level of porosity must be present in the coating. However, the porosity can be controlled with relatively minor changes in the spray parameters. ${ }^{14}$ Titanium dioxide $\mathrm{TiO}_{2}$ occurs in three crystal forms: anatase, rutile and brookite. The most common natural form of $\mathrm{TiO}_{2}$ is rutile, and for better durability anatase and rutile are used in practice. Rutile and anatase crystallize in a tetragonal crystal form, while brookite crystallizes have an orthorhombic crystal form. The most common form of $\mathrm{TiO}_{2}$ in nature, and also the most thermodynamically stable, is rutile. By heating anatase or brookite at a high enough temperature, they turn into a thermodynamically more stable modification, rutile. ${ }^{15}$ Anatase is not thermodynamically stable, it is kinetic, and when heated to a temperature of $550{ }^{\circ} \mathrm{C}$ to $1000{ }^{\circ} \mathrm{C}$, depending on the impurities, it moves immediately to the equilibrium rutile phase. $\mathrm{TiO}_{2}$ coatings deposited by atmospheric plasma spraying, with a powder in a well molten state, consist of a basic rutile phase and an anatase phase of about $10 \%$ to $15 \% .^{16,17}$ The x-ray diffraction (XRD; $\mathrm{Cu}-K_{\alpha}$ radiation) of $\mathrm{TiO}_{2}$ coatings, deposited by atmospheric plasma spraying, show that in the microstructure of $\mathrm{TiO}_{2}$ coatings rutile dominates as the main phase. However, in addition to rutile in the microstructure of the coating present are, phases such as anatase/brookite and the Magneli phase. ${ }^{18}$ When $\mathrm{TiO}_{2}$ is heated and melted in a reduction atmosphere such as the atmosphere of a plasma jet containing $\mathrm{H}_{2}, \mathrm{TiO}_{2}$ oxide is easily reduced to lower valence oxides such as the Magneli phase $\mathrm{Ti}_{\mathrm{n}} \mathrm{O}_{2 \mathrm{n}-1}(n=4$ to 10$) .{ }^{19}$ The $\mathrm{Ti}_{4} \mathrm{O}_{7}$ Magneli phase present in the microstructure of the coating is the result of high temperature and the reducing atmosphere of the plasma jet. ${ }^{18}$ The structure and mechanical properties of $\mathrm{TiO}_{2}$ coatings are directly related to the depositing parameters. The powder coating process parameters affect the microstructure of coatings, which are very important for various applications..$^{20,21}$ The microstructure of the coating affects the microhardness, toughness, tensile bond strength, and the behavior of the coating in service. ${ }^{22,23}$

Plasma spray $\mathrm{TiO}_{2}$ coatings play an important role in the design of engineering components in order to increase their durability and performance under different operating conditions. In this study layers of $\mathrm{TiO}_{2}$ coatings were deposited using plasma spraying under atmospheric pressure at plasma spray distances of $100 \mathrm{~mm}$ and $110 \mathrm{~mm}$. The aim of this study was to investigate the mechanical properties and microstructure of the coating layers of titanium dioxide $\left(\mathrm{TiO}_{2}\right)$, which will be applied in the production of biomedical implants. The microstructure of the coatings was analyzed by light microscopy, and the morphology of the powder, coating surface and fracture morphology was analyzed on the SEM (scanning electron microscope).

\section{MATERIALS AND EXPERIMENTAL PART}

Powder Metco 102 of the company Sulzer Metco was used for the depositing and analyzing of the layers of $\mathrm{TiO}_{2}$ coatings. The oxide powder $\mathrm{TiO}_{2}$ was produced by the method of melting and subsequent grinding of the cast blocks to various granulation sizes. The melting point of $\mathrm{TiO}_{2}$ powder is $1843{ }^{\circ} \mathrm{C}$. For this study, the powder used had a granule range of $11-45 \mu \mathrm{m} .{ }^{14}$ Figure 1 shows an SEM image of the morphology of the $\mathrm{TiO}_{2}$ powder particles. The SEM micrographs show that the $\mathrm{TiO}_{2}$ powder grains have an irregular and angular shape with sharp edges.

The samples for microhardness testing and microstructure evaluation were made of Č.4171 (X15Cr13 EN10027) steel in a thermally unprocessed state, size $70 \mathrm{~mm} \times 20 \mathrm{~mm} \times 1.5 \mathrm{~mm}$, and for testing bond tensile strength size $\varnothing 25 \mathrm{~mm} \times 50 \mathrm{~mm}$ according to the Pratt \& Whitney standard. ${ }^{24}$ The investigation of the microhardness of layers of the $\mathrm{TiO}_{2}$ coatings was made using the method HV0.3. The measurements were taken in the direction along the lamellae in the middle and at the ends of the sample. Five readings were made at three measuring points, and the paper shows the mean value of the microhardness. Testing of the tensile bond strength was carried out at room temperature on hydraulic equipment at a rate of $10 \mathrm{~mm} / \mathrm{min}$. Tested were five specimens, and the paper shows the mean value. Microstructural analysis of the coatings was performed under a light microscope. Determining the share of pores in the coating was done by analyzing five photographs at $200 \times$ magnification. Through tracing paper micro pores were labeled and shaded and their total surface was calculated in regard to the total surface of the micrographs. The percentage share of pores in the coating was measured by software analysis of OM images. This paper shows the mean values of the share of the pores. The morphology of the

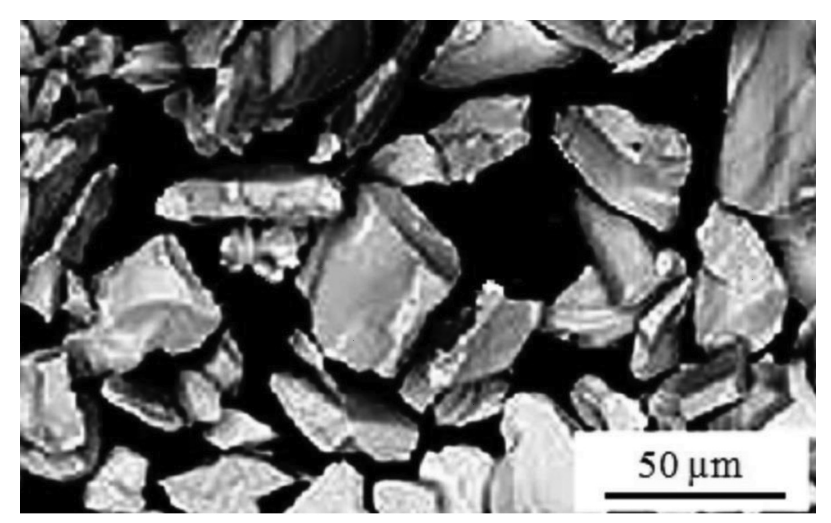

Figure 1: $\mathrm{SEM}$ of $\mathrm{TiO}_{2}$ powder particles 
powder particles, coating surface and coating fracture was analyzed under an SEM. The $\mathrm{TiO}_{2}$ powder was deposited with a robotic plasma-spray system, from thecompany Plasmadyne, and a plasma gun SG-100, which is fully automated with controlled plasma-spray parameters. The plasma gun SG-100 is composed of a cathode type K 1083-112, anode type A 2083-155 and a gas injector type GI 1083 - 113. Argon (Ar) in combination with hydrogen $\left(\mathrm{H}_{2}\right)$ was used as a plasma gas with up to $40 \mathrm{~kW}$ of power. The $\mathrm{TiO}_{2}$ coating layers were deposited at a stand-off distance of $100 \mathrm{~mm}$ and $110 \mathrm{~mm}$ of the plasma gun from the substrate. Other parameters of the plasma-spray deposition of the $\mathrm{TiO}_{2}$ powder were constant and are presented in Table $\mathbf{1}$. Before the process of depositing the surface of the substrate was roughened with white corundum particles size $0.7-1.5 \mathrm{~mm}$. Coatings were formed with thicknesses from $0.30 \mathrm{~mm}$ to $0.32 \mathrm{~mm}$.

Table 1: Plasma spray parameters

\begin{tabular}{|l|c|c|}
\hline \multicolumn{1}{|c|}{ Deposition parameters } & \multicolumn{2}{c|}{ Values } \\
\hline Plasma current, $I(\mathrm{~A})$ & 750 & 750 \\
\hline Plasma voltage, $U(\mathrm{~V})$ & 45 & 45 \\
\hline Primary plasma gas flow rate, Ar (L/min) & 50 & 50 \\
\hline Secondary plasma gas flow rate, He (L/min) & 8 & 8 \\
\hline Carrier gas flow rate, Ar (L/min) & 7 & 7 \\
\hline Powder feed rate (g/min) & 40 & 40 \\
\hline Stand-off distance $(\mathrm{mm})$ & 100 & 110 \\
\hline
\end{tabular}

\section{RESULTS AND DISCUSSION}

The $\mathrm{TiO}_{2}$ coatings had different values of microhardness and tensile bond strength, depending on the stand-off distance of the plasma gun from the substrate. The layers of $\mathrm{TiO}_{2}$ coating deposited with a smaller plasma distance $(100 \mathrm{~mm})$ had a lower value of microhardness $785 \mathrm{HV} 0.3$. The $\mathrm{TiO}_{2}$ layers deposited with a plasma distance of $110 \mathrm{~mm}$ measured a higher microhardness value of $823 \mathrm{HV} 0.3$. Different values of microhardness in the deposited $\mathrm{TiO}_{2}$ layers are the result of different amounts of micro-pores in the coating. This was confirmed by image analysis while determining the total content of micro pores in the deposited layers. In

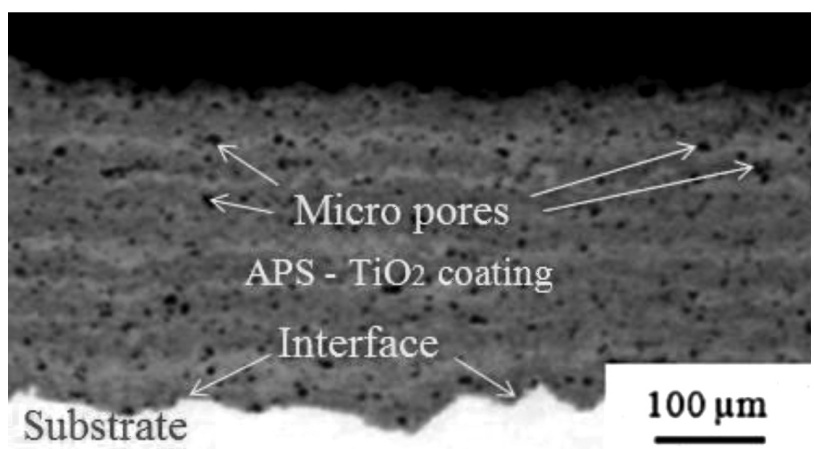

Figure 2: OM micrograph of plasma-sprayed coatings of $\mathrm{TiO}_{2}$ with plasma-spray distance of $100 \mathrm{~mm}$ examining the coatings for tension, all the coatings were destroyed at the substrate/coating interface due to good preparation of the substrate and a good bond of deposited layers with the substrate. The measured values of the tensile bond strength were directly dependent on the plasma-spray stand-off distance. $\mathrm{TiO}_{2}$ coatings deposited at a smaller distance $(100 \mathrm{~mm})$ had a lower value of tensile bond strength of $29 \mathrm{MPa}$. The smaller distance of the plasma gun resulted in shorter retention of the powder particles in the plasma, which resulted in lesser melting of the powder particles relative to the coating deposited with the larger plasma spray distance. The coatings deposited from the plasma spraying with the larger stand-off distance had a greater bond strength value of $36 \mathrm{MPa}$, which indicates that there is a smaller content of pores present in them, as confirmed by the analysis of the images from the light microscope. The mechanical properties of the deposited layers of oxide ceramics $\mathrm{TiO}_{2}$ with a plasma distance of $110 \mathrm{~mm}$ are good and they indicate that the applied powder was deposited with the optimal deposition parameters. The measured values of the mechanical properties were consistent with the microstructure of the deposited layers, which the analysis of the microstructures with optical and scanning electron microscopes confirmed.

Figures $\mathbf{2}$ and $\mathbf{3}$ show the microstructure of layers of the $\mathrm{TiO}_{2}$ coating deposited with a plasma gun at distances of $100 \mathrm{~mm}$ and $110 \mathrm{~mm}$. The metallographic analysis of the coatings showed that the microstructure of the ceramic $\mathrm{TiO}_{2}$ coatings was affected by the plasma-spraying distance.

The microstructure of the $\mathrm{TiO}_{2}$ oxide coating deposited with a plasma spray spacing of $100 \mathrm{~mm}$, which had lower values of microhardness and bond strength, indicates that in the deposited layers there are higher proportions of pores. Analyses of the images showed that the proportion of pores in the layers was $5.2 \%$. The microstructure of the coatings deposited with a plasma-spray spacing of $110 \mathrm{~mm}$, which had better mechanical properties, indicates that there is a smaller share of pores in the layers. The larger plasma-spray distance enabled the ceramic particles to melt better and also be deposited more evenly on the base with a smaller share of pores of $3.8 \%$ due to prolonged time in the plasma. Completely molten

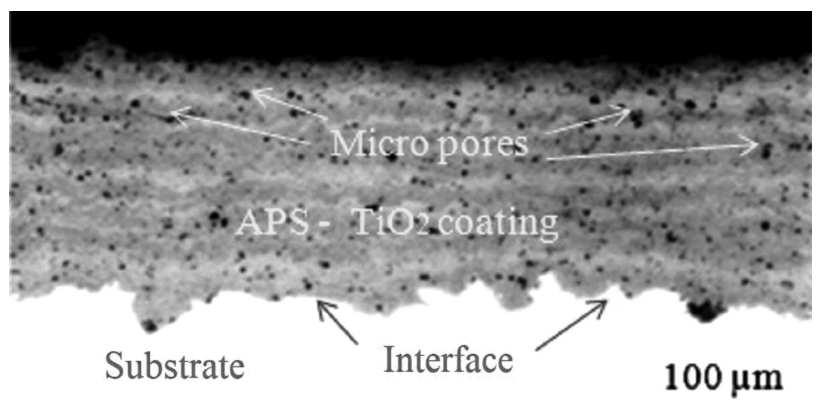

Figure 3: OM micrograph of plasma-sprayed coatings of $\mathrm{TiO}_{2}$ with plasma-spray distance of $110 \mathrm{~mm}$ 
powder particles are more easily deformed and more regularly shape lamellae in collision with the substrate and previously deposited layer. In this way, in the coating, layers are formed with a lower content of the pores having greater cohesive strength and the tensile bond strength. The micrographs clearly show the inter boundaries of the joint between the coating layers and the substrate. The inter boundaries are clean, which indicates good surface preparation of the substrate prior to the powder depositing process. At the inter boundary, after roughening, there are no remains of corundum particles present, which allowed good adhesion of the deposited coating layers with the substrates. Along the inter boundary there were no discontinuities of deposited layers or defects such as micro and macro cracks, peeling and flaking of the coating from the surface of the substrate. The layers are uniformly deposited on the substrates. There are no micro- or macro-cracks present in the coating layers.

Figure 4 shows an OM micrograph of the coating deposited with a plasma-spray distance of $110 \mathrm{~mm}$ at a higher magnification, to more clearly show the microstructure of the coating in the deposited state.

In the microstructure of the coating, clearly visible are dark and light lamellae of titanium oxide which differ in nuances. The microstructure is dominated by the main rutile phase with which, due the well-melted powder particles, also present is the anatase phase. ${ }^{16,17}$ In addition to the rutile and anatase phases, the brookite phase is also present in the microstructure of the coating. ${ }^{18}$ Due to the reductioning atmosphere, which is derived from the secondary $\mathrm{H}_{2}$ gas, and the high temperature of the plasma jet, the microstructure of the coating also contains the $\mathrm{Ti}_{4} \mathrm{O}_{7}$ Magneli phase. $\mathrm{TiO}_{2}$ is, due to hydrogen, always and easily reduced $\left(\mathrm{Ti}_{\mathrm{n}} \mathrm{O}_{2 \mathrm{n}-1} n=4\right.$ to 10$)$ to a lower valence oxide $\mathrm{Ti}_{4} \mathrm{O}_{7}{ }^{18,19}$ The microstructure clearly shows the pores of irregular shape indicated by yellow arrows. There were no non-melted powder particles in the coating, which confirms that the powder particles were deposited with the optimum deposition parameters.

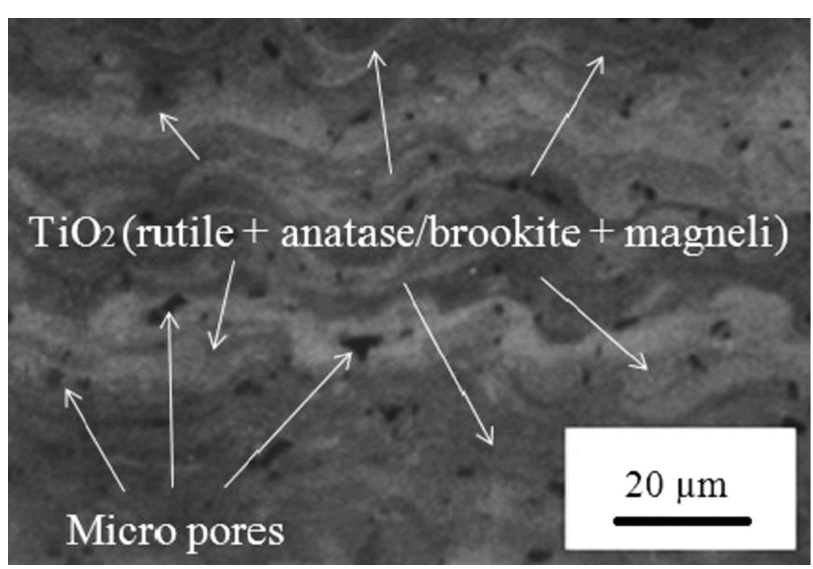

Figure 4: $\mathrm{OM}$ micrograph of plasma-sprayed coatings of $\mathrm{TiO}_{2}$ with a plasma-spray distance of $110 \mathrm{~mm}$

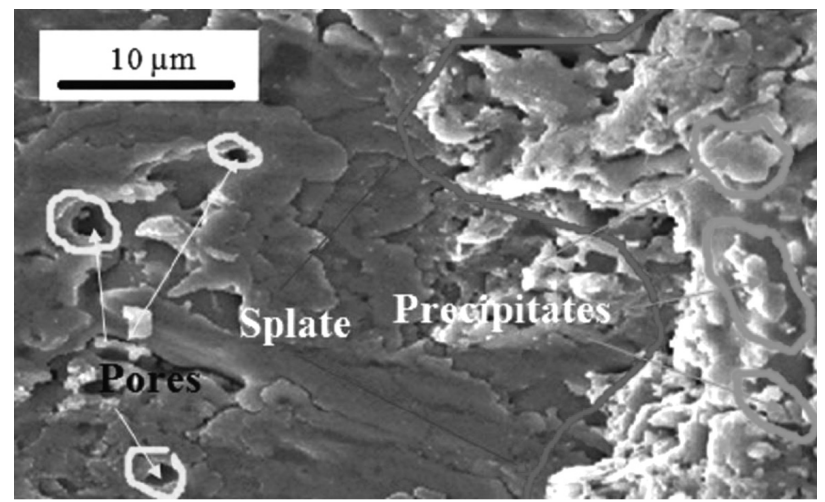

Figure 5: SEM micrographs of $\mathrm{TiO}_{2}$ coating surface

Figure 5 shows the SEM micrograph of the surface of the $\mathrm{TiO}_{2}$ coating deposited with a plasma spray distance of $110 \mathrm{~mm}$. Analysis of the surface morphology of the $\mathrm{TiO}_{2}$ coating showed complete melting and proper dispersal of the powder particles. In the SEM micrographs the boundary between the dispersed melted particles is marked by a red line. On the surface of the coating there are no coarse pores observed. The SEM micrographs clearly show the fine pores circled in yellow. On the coating surface are clearly visible fine precipitates circled in green, size up to $5 \mu \mathrm{m}$, which were formed by breaking off of the ends of the molten drops in collision with the substrate. The broken-off ends of the drops of molten particles harden as a sediment in the deposited coating layers.

Figure 6 shows micrographs of the fracture of the layers of $\mathrm{TiO}_{2}$ coatings deposited with a plasma spray spacing of $110 \mathrm{~mm}$. At the fracture line is the morphology of the $\mathrm{TiO}_{2}$ coatings fracture. The coating fracture is brittle, which is a characteristic of ionic crystals. Through the coating layers are clearly visible micro cracks on the inter boundaries of the lamellae and through the lamellae caused by the transverse fracture of the coating. The micrographs clearly show the interlamellar pores, size up to $10 \mu \mathrm{m}$, which are present throughout the cross-section of the coating and did not significantly affect the cohesion and adhesion strength.

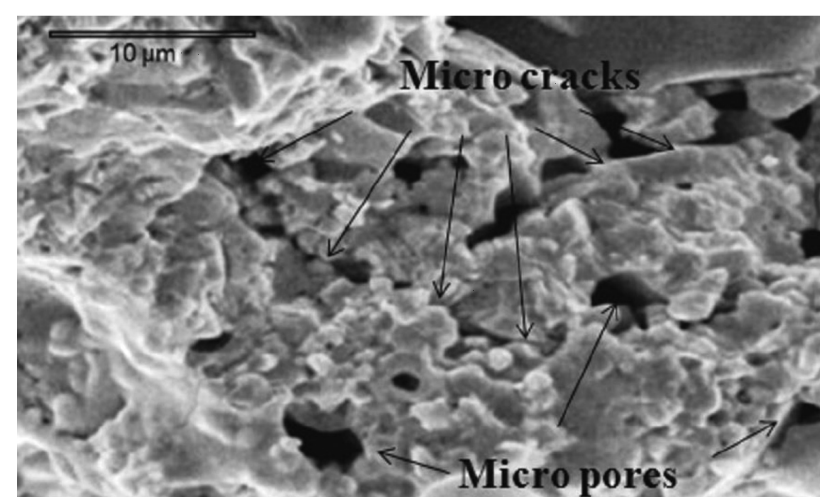

Figure 6: $\mathrm{SEM}$ of $\mathrm{TiO}_{2}$ coating fracture morphology 


\section{CONCLUSIONS}

Using the atmospheric plasma spray (APS) process coatings of titanium dioxide, $\mathrm{TiO}_{2}$, were deposited at plasma-gun distances of $100 \mathrm{~mm}$ and $110 \mathrm{~mm}$ from the substrate. The thickness of the deposited coatings was $0.30 \mathrm{~mm}$ to $0.32 \mathrm{~mm}$. The mechanical properties of the coating were investigated and the microstructures of the deposited layers were analyzed on the optical microscope (OM) and the scanning electron microscope (SEM), based on which the following conclusions were made.

The mechanical properties of the $\mathrm{TiO}_{2}$ coatings and the microstructure of deposited layers were influenced by the distance of the plasma gun from the substrate. The greater distance of the plasma gun from the substrate increased the mechanical characteristics and improved the microstructure of the deposited layers of $\mathrm{TiO}_{2}$ due to longer retention of the powder particles in the plasma, which then allowed better melting of the powder. With a greater plasma distance, coatings with higher values of microhardness $823 \mathrm{HV} 0.3$ and tensile bond strength of 36 $\mathrm{MPa}$ were deposited. The coatings deposited with a smaller plasma-gun distance, due to shorter retention of powder in the plasma, had a lower microhardness value of $785 \mathrm{HV} 0.3$ and tensile strength $29 \mathrm{MPa}$. The values of the microhardness and the tensile strength of the joint were in correlation with their microstructures.

The structure of the deposited $\mathrm{TiO}_{2}$ coatings is lamellar. Micro pores are present in the coatings. The layers deposited at a plasma distance of $100 \mathrm{~mm}$ had a $5.2 \%$ share of pores, and the layers deposited with a plasma distance of $110 \mathrm{~mm}$ had $3.8 \%$ micro pores. The microstructure of $\mathrm{TiO}_{2}$ the coatings deposited with well-melted powder with a $110 \mathrm{~mm}$ plasma distance consisted of the dominant rutile phase and anatase phase. In addition to the rutile and anatase phases, the brookite and Magneli phases are also present in the microstructure of the coating. The $\mathrm{TiO}_{2}$ at high temperature in a reducing atmosphere of $\mathrm{H}_{2}$ was easily reduced $\mathrm{Ti}_{n} \mathrm{O}_{2 n-1}(n=4$ to 10) to the lower-valence Magneli oxide $\mathrm{Ti}_{4} \mathrm{O}_{7}$.

\section{Acknowledgment}

This work was supported by The Serbian Ministry of Education, Science and Technological Development of the Republic of Serbia (Contract No. 451-03-68/202014/200287).

\section{REFERENCES}

${ }^{1}$ P. K. Chu, Plasma-Treated Biomaterials, IEEE Trans. Plasma Sci., 35 (2007) 181-187, doi:10.1109/TPS.2006.888587

${ }^{2}$ D. Chuanxian, H. Bingtang, L. Huiling, Plasma-sprayed wear-resistant ceramic and cermet coating materials, Thin Solid Films, 118 (1984) 485-493, doi:10.1016/0040-6090(84)90277-3

${ }^{3}$ Y. Wang, J. Yuansheng, W. Shizhu, The analysis of the friction and wear mechanisms of plasma-sprayed ceramic coatings at $450{ }^{\circ} \mathrm{C}$, Wear, 128 (1988) 265-276, doi:10.1016/0043-1648(88)90063-4
${ }^{4}$ G. X. Shen, Y. C. Chen, C. J. Lin, Corrosion protection of 316L stainless steel by a $\mathrm{TiO}_{2}$ nanoparticle coating prepared by sol-gel method, Thin Solid Films, 489 (2005) 130-136, doi:10.1016/ j.tsf.2005.05.016

${ }^{5}$ H. Wang, Z. Wang, H. Hong, Y. Yin, Preparation of cerium-doped $\mathrm{TiO}_{2}$ film on 304 stainless steel and its bactericidal effect in the presence of sulfate-reducing bacteria (SRB), Mater. Chem. Phys., 124(2010) 791-794, doi:10.1016/j.matchemphys.2010.07.063

${ }^{6}$ S. Cherneva, R. Iankov, N. Radic, B. Grbic, M. Datcheva, D. Stoychev, Nano-indentation investigations of the mechanical properties of thin $\mathrm{TiO}_{2}, \mathrm{WO}_{3}$ and their composites layers, deposited by spray pyrolysis, Mater. Tehnol., 51(2017) 75-83, doi:10.17222/ mit.2015.216

${ }^{7}$ A. Balamurugan, S. Kannan, S. Rajeswari, Evaluation of $\mathrm{TiO}_{2}$ coatings obtained using the sol-gel technique on surgical grade type 316L stainless steel in simulated body fluid, Mater. Lett., 59 (2005) 3138-3143, doi:10.1016/j.matlet.2005.05.036

${ }^{8}$ N. Arconada, A. Durán, S. Suárez, R. Portela, J. M. Coronado, B. Sánchez, Y. Castro, Synthesis and photocatalytic properties of dense and porous $\mathrm{TiO}_{2}$-anatase thin films prepared by sol-gel, Appl. Catal., B, 86(2009) 1-7, doi:10.1016/j.apcatb.2008.07.021

${ }^{9}$ A. Kleiman, A. Márquez, M. L. Vera, J. M. Meichtry, M. I. Litter, Photocatalytic activity of $\mathrm{TiO}_{2}$ thin films deposited by cathodic arc, Appl. Catal., B, 101 (2011) 676-681, doi:10.1016/j.apcatb.2010. 11.009

${ }^{10}$ M. A. Hamid, I. A. Rahman, Preparation of titanium dioxide $\left(\mathrm{TiO}_{2}\right)$ thin films by sol-gel dip coating method, Malaysian Journal of Chemistry, 5(2003) 86-9

${ }^{11}$ R. Z. LeGeros, Properties of osteoconductive biomaterials: calcium phosphates, Clin. Orthop. Relat. Res., 395 (2001) 81-98, doi:10.1097/00003086-200202000-00009

${ }^{12}$ W. Suchanek, M. Yoshimura, Processing and Properties of Hydroxyapatite-Based Biomaterials for Use as Hard Tissue Replacement Implants, J. Mater. Res., 13 (1998) 94-117, doi:10.1557/ JMR.1998.001

${ }^{13}$ X. Liu, X. Zhao, C. Ding, Introduction of Bioactivity to Plasma Sprayed $\mathrm{TiO}_{2}$ Coating with Nanostructured Surface by Post-Treatment, Proc. of the International Thermal Spray Conference, Seattle, 2006, 53-57

${ }^{14}$ Material Product Data Sheet, Pure Titanium Oxide Powders for Thermal Spray Coatings, 2012, DSMTS-0065.4 Sulzer Metco

${ }^{15}$ A. Mehrizad, P. Gharbani, S. M. Tabatabii, Synthesis of nanosized $\mathrm{TiO}_{2}$ powder by Sol-Gel method in acidic conditions, J. Iran. Chem. Res. 2 (2009) 145-149

${ }^{16}$ A. Ohmori, H. Shoyama, S. Matsusaka, K. Ohashi, K. Moriya, C.-J. Li, Thermal Spray: Surface Engineering via Applied Research, Publisher: ASM International, Montreal, 2000, 317-323

${ }^{17}$ C. Coddet, A. Ohmori, C.-J. Li, H. Liao, G. Bertrand, C. Meunier, D. Klein, Proc. $1^{\text {st }}$ Int. Symp. Environmental Materials and Recycling, Osaka, 2001, 3-6

${ }^{18}$ R. S. Lima, B. R. Marple, From APS to HVOF spraying of conventional and nanostructured titania feedstock powders: a study on the enhancement of the mechanical properties, Surf. Coat. Technol., 200 (2006) 3428-3437, doi:10.1016/j.surfcoat.2004.10.137

${ }^{19}$ M. Miyayama, K. Koumoto, H. Yanagida, Engineering Propereties of Single Oxide, in Engineered Materials Handbook, Ceramic and Glasses, vol. 4, Ed., Schneider, Published: ASM International, Materials Park, OH, 1991, 748

${ }^{20}$ A. Vencl, M. Mrdak, P. Hvizdos, Tribological Properties of WC-Co/NiCrBSi and Mo/NiCrBSi Plasma Spray Coatings under Boundary Lubrication Conditions, Tribology in Industry, 39 (2017) 183-191, doi:10.24874/ti.2017.39.02.04

${ }^{21} \mathrm{M}$. Mrdak, Characterization of Composite Bio Inert APS- $\mathrm{Al}_{2} \mathrm{O}_{3} 25 \mathrm{wt} . \%\left(\mathrm{ZrO}_{2} 8 \% \mathrm{Y}_{2} \mathrm{O}_{3}\right)$, Journal Materials Protection, 58 (2017) 509-514, doi:10.5937/ZasMat1704509M

${ }^{22}$ M. Mrdak, Č. Lačnjevac, M. Rakin, Mechanical and structural features of $\mathrm{Nb}$ coating layers deposited on steel substrates in a vacuum chamber, Journal Materials Protection, 59 (2018) 167-172, doi:10.5937/ZasMat1802167M 
M. MRDAK et al.: MECHANICAL AND STRUCTURAL CHARACTERISTICS OF ATMOSPHERIC PLASMA-SPRAYED ...

${ }^{23}$ M. Mrdak, Č. Lačnjevac, M. Rakin, N. Bajić, Characterization of tantalum coatings deposited using vacuum plasma spray process, Journal Materials Protection, 59 (2018) 489-494, doi:10.5937/ ZasMat1804489M

${ }^{24}$ Turbojet Engine - Standard Practices Manual (PN 582005), Publisher: Pratt \& Whitney Aircraft Group, East Hartford, 2002 